\title{
Citra Diri dalam Instagram Jokowi
}

\author{
Cindy, Wulan Purnama Sari \\ Cindytan507@gmail.com,wulanp@fikom.untar.ac.id \\ Fakultas Ilmu Komunikasi, Universitas Tarumanagara
}

\begin{abstract}
Communication is one of the basic human basic needs in living life as a social creature. Along with the development of the times that there is technology developing until social media is very developed, one of which is developing social media is Instagram which is now present in the middle of the community. The community can use Instagram social media which is currently also as a media that can make everyone able to communicate both remotely and short distance. Instagram can also see how one's self-image in an existing social media like in a post on Instagram that can show someone's activities. One of them is Instagram owned by the President of the Republic of Indonesia, Joko Widodo, who is fairly active on Instagram social media, despite having a very crowded activity. Jokowi also showed his image through every post uploaded on Instagram. President Joko Widodo is very active in uploading every post whether in political activities, family or even community activities. In this study, the author wants to find out how the attitude of a President of the Republic of Indonesia Joko Widodo on social media Instagram on society, family, and politics. The author will analyze each of Jokowi's posts from June to August to find out how the attitude of a President of the Republic of Indonesia on social media Instagram. The purpose of the research to be achieved by the writer is to know and describe the self-image in Instagram Jokowi.
\end{abstract}

Keywords: instagram, self image, social media

\begin{abstract}
Abstrak
Komunikasi merupakan salah satu pokok yang menjadi kebutuhan dasar manusia dalam menjalani kehidupan sebagai makhluk sosial. Seiring perkembangan zaman yang ada teknologi berkembang hingga media sosial pun sangat berkembang, salah satunya media sosial yang berkembang adalah Instagram yang saat ini telah hadir ditengah masyarakat. Masyarakat dapat menggunakan media sosial Instagram yang saat ini juga sebagai media yang dapat membuat setiap orang dapat berkomunikasi baik secara jarak jauh maupun jarak dekat. Instagram juga bisa melihat bagaimana citra diri seseorang dalam sebuah media sosial yang ada seperti pada postingan di Instagram yang dapat memperlihatkan kegiatan seseorang. Salah satunya Instagram milik Presiden Republik Indonesia Joko Widodo yang terbilang aktif di media sosial Instagram, meski memiliki kegiatan yang sangat padat. Jokowi juga menunjukkan citra dirinya melalui setiap postingan yang diunggah di Instagram. Presiden Joko Widodo sangat aktif dalam mengunggah setiap postingan baik dalam kegiatan politik, keluarga bahkan sampai kegiatan bersama masyarakat. Dalam penelitian ini, penulis ingin mengetahui bagaimana penyikapan diri seorang Presiden Republik Indonesia Joko Widodo dalam media sosial Instagram terhadap masyarakat, keluarga, dan politik. Penulis akan menganalisis setiap postingan Jokowi dari bulan Juni hingga Agustus untuk mengetahui bagaimana penyikapan diri seorang Presiden Republik Indonesia dalam media sosial Instagram. Tujuan penelitian yang ingin dicapai oleh penulis adalah untuk mengetahui dan mendeskripsikan Citra diri dalam Instagram Jokowi
\end{abstract}

Kata Kunci: citra diri, instagram, media sosial 


\section{Pendahuluan}

Seiring perkembangan zaman yang ada, teknologi dan informasi pun juga berkembang pesat. Kini hadirnya new media atau bisa disebut media baru menjadi sebuah akses untuk mempermudah seseorang dalam menjalani komunikasi. Bahkan setiap media pun menjadi sebuah kebutuhan primer bagi setiap orang yang ada. Karena adanya kebutuhan informasi, hiburan, pendidikan, serta rasa keingintahuan lebih tentang belahan bumi yang berbeda. Kini munculnya sebuah media baru yang disebut juga adalah Media sosial yang menjadi suatu trend komunikasi dalam menciptakan suatu karakteristik seseorang melalui perilaku yang ditunjukkan seseorang dalam menggunakan media sosial. Media sosial adalah sebuah media online, dengan para penggunanya yang cepat dan bisa berpartisipasi, berbagi, dan membuat isi seperti blog, jejaring sosial, wiki, forum dan dunia virtual. Media sosial merupakan bentuk yang paling umum yang digunakan oleh masyarakat di seluruh dunia. Media sosial sebagai "sebuah kelompok aplikasi berbasis internet yang membangun di atas dasar ideologi dan teknologi Web 2.0, dan yang memungkinkan penciptaan dan pertukaran usergenerated content" (Kaplan \& Haenlein, 2010). Beberapa contoh media sosial yang sedang berkembang saat ini yaitu Instagram, YouTube, Twitter, Facebook dan lainlain.

Seorang pengguna media sosial pasti memiliki berbagai motivasi dan keinginan tersendiri dalam menggunakan media sosial, baik sekedar untuk berkomunikasi, untuk mencari tahu perkembangan zaman, bahkan untuk berbagi informasi maupun untuk mengikuti salah satu trend saat ini sebagai bentuk citra diri seseorang . Morton (dalam Dayakisni, 2009) mengatakan bahwa citra diri seseorang merupakan kegiatan membagi perasaan dan informasi yang akrab dengan orang lain. Citra diri dapat bersifat deskriptif atau evaluatif. Deskriptif artinya individu melukiskan berbagai fakta mengenai diri sendiri yang mungkin belum diketahui oleh pendengar seperti, jenis pekerjaan, alamat, dan usia, sedangkan evaluatif artinya individu mengemukakan pendapat atau perasaan seperti tipe orang yang disukai atau hal-hal yang tidak disukai atau dibenci. Sebagian orang menggunakan media sosial hanya untuk orang terdekat saja akan tetapi ada juga yang menggunakan media sosial untuk mengekspos kehidupannya di dalam jejaring media sosial yang ada. Perkembangan pengguna media sosial di Indonesia sangat berkembang pesat.

Menurut riset Nielsen Januari 2019 - April 2019 menunjukan tingkat pertumbuhan pengguna internet di Indonesia menghabiskan waktu 1,5 jam sehari untuk berinternet. Menurut hasil riset Cuponation jumlah pengguna Instagram di Indonesia mencapai 56 juta penduduk atau 20,97\% dari total populasi di Tanah Air. Pengguna Instagram terbanyak rentang dari usia 18 tahun hingga 24 tahun (https://www.nielsen.com/id/en/press-releases/2019/konsumen-indonesia-tetapoptimistis-di-akhir-tahun-2018/). Dalam kehidupan sehari-hari, pengungkapan diri atau citra diri seseorang yang berlangsung tidak hanya dalam komunikasi dan interaksi antar manusia, tetapi dapat juga terjadi melalui media perantara, yaitu melalui media sosial. Citra diri seseorang dapat melalui media sosial ini sering terjadi dalam bentuk status, foto/video, komentar dan lain-lainya terkait dengan kejadian yang sedang dialami maupun perasaan yang dimiliki yang dapat dibagikan oleh para pengguna media sosial lainya. Media sosial juga banyak digunakan untuk mengekspresikan perasaan seseorang yang sedang dialami, hal ini merupakan salah satu bentuk citra diri seseorang. Seperti salah satunya seperti Instagram milik Presiden Jokowi yang mendapatkan Jumlah Followers 24,1 M per tanggal 2 September 2019. 
Berdasarkan penelitian terdahulu yang telah dilakukan oleh Azeharie \& Sari (2015), dengan judul Penyikapan diri Ibas Yudhoyono dalam Instagram dan reaksi Ani Yudhoyono terhadap postingan Instagram Ibas . Dalam penelitian ini penulis dapat melihat bagaimana penyikapan diri Ibas yudhoyono dalam Instagram yang terdapat dalam 3 bagian citra diri politik, masyarakat, dan keluarga dan juga dibagi ke dalam 5 kategori antar komunikasi personal seperti; empati, rasa positif, dukungan, kesetaraan dan keterbukaan. Seperti yang peneliti lakukan pada penelitian ini.

Penelitian ini pun dilakukan untuk mengetahui apakah media sosial memiliki peran sebagai sarana citra diri Jokowi dan apakah untuk mendeskripsikan bagaimana citra diri dalam media sosial Instagram yang ditampilkan Jokowi.

\section{Metode Penelitian}

Dalam penelitian ini, peneliti menggunakan pendekatan kualitatif yang bersifat deskriptif. Penelitian kualitatif secara harfiah merupakan jenis penelitian yang temuantemuannya tidak diperoleh melalui prosedur kuantifikasi, perhitungan, statistic, atau bentuk lainnya yang menggunakan angka-angka (Gunawan, 2014). Penelitian ini bertujuan untuk mendapatkan pemahaman yang mendalam mengenai suatu masalah dalam sebuah postingan Instagram Jokowi dan mendeskripsikannya secara terperinci.

Dalam penelitian ini, menggunakan pendekatan penelitian kualitatif deskriptif menjadi pendekatan yang terbaik, karena dalam penelitian ini berusaha untuk menjelaskan sebuah "Citra diri dalam Instagram Jokowi".

Maka cara yang digunakan dalam penelitian ini adalah metode triangulasi. Triangulasi adalah teknik pemeriksaan keabsahan data yang memanfaatkan sesuatu yang lain. Diluar data itu sendiri untuk keperluan pengecekan atau sebagai pembanding terhadap data itu (Moleong, 2012). Triangulasi dapat diartikan juga sebagai penggunaan data atau lebih sumber untuk mendapatkan gambaran yang menyeluruh mengenai suatu fenomena yang diteliti (Herdiansyah, 2010). Peneliti dapat me re-check temuan dengan cara menggunakan triangulasi kejujuran peneliti, sumber, metode dan teori (Bungin, 2010).

Menurut Denzin (dalam moleong, 2009) triangulasi data dibedakan menjadi empat macan sebagai teknik pemeriksaan yang memanfaatkan penggunaan sumber, metode, penyidik, dan teori. Triangulasi dengan sumber berarti membandingkan serta mengecek kembali hasil derajat kepercayaan suatu informasi yang diperoleh melalui waktu dan alat yang berbeda dalam penelitian kualitatif. Untuk mencapai proses triangulasi sumber maka hal yang dapat dilakukan adalah (1) membandingkan data hasil pengamatan dengan hasil wawancara diperoleh; (2) membandingkan apa yang dikatakan seseorang secara umum dengan apa dikatakan secara pribadi; (3) membandingkan apa yang dikatakan orang-orang mengenai situasi penelitian dengan dikatakannya sepanjang waktu; (4) membandingkan keadaan pandangan masyarakat sepanjang waktu; (5) membandingkan hasil wawancara dengan isi suatu dokumen yang berkaitan (Moleong, 2009).

Pada penelitian mengenai Citra diri dalam Instagram Jokowi ini, maka penelitian akan membandingkan data atau melakukan pengecekan dengan data yang lainnya untuk keabsahan data dan kebenarannya dengan cara triangulasi yang memanfaatkan pengguna sumber. Penggunaan cara tersebut karena dalam penelitian ini, sumber merupakan hal yang paling mendukung untuk mendapatkan hasil penelitian secara lengkap dan tepat. 


\section{Hasil penemuan dan diskusi}

Menurut hasil penelitian penulis pada Instagram Jokowi bulan Juni-Agustus 2019 berdasarkan grafik berikut:

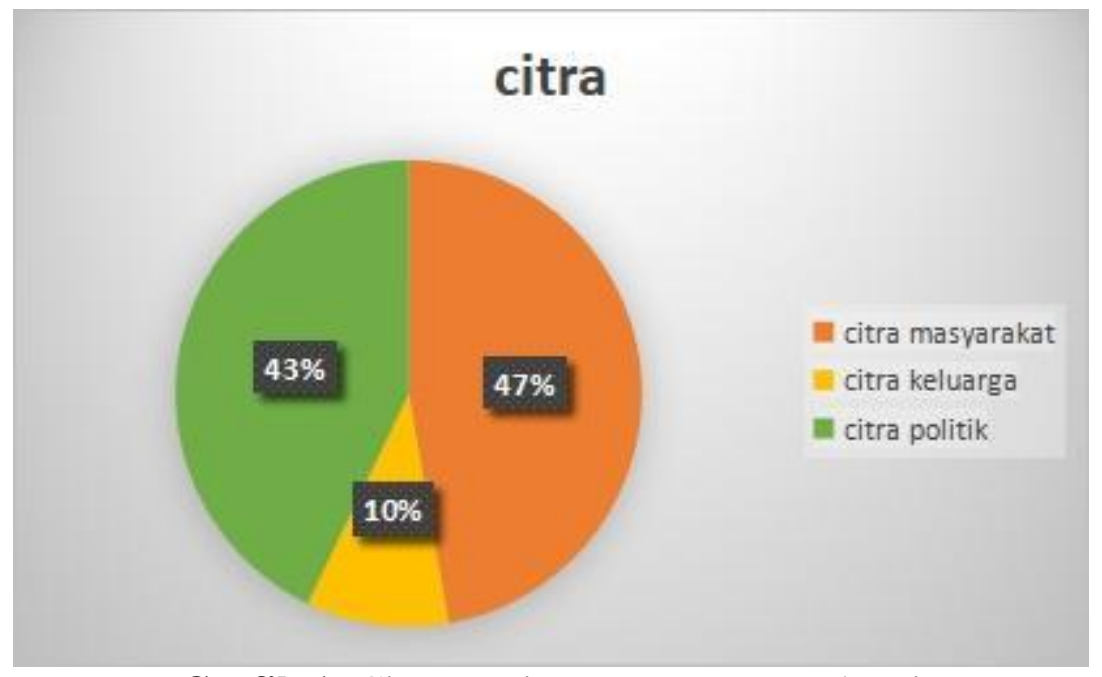

Grafik 1: Citra Postingan Instagram Jokowi

Melalui Instagram Presiden Jokowi dapat dilihat bagaimana seorang Presiden Jokowi dalam citra dirinya di media sosial baik terhadap masyarakat, keluarga, maupun politik. Hal tersebut dapat dibuktikan melalui postingan Presiden Jokowi dari bulan Juni-Agustus 2019 yang menunjukan citra dirinya terhadap keluarga sebanyak 18, politik sebanyak 78 dan masyarakat sebanyak 86 buah postingan yang ada didalam Instagram Jokowi. Beliau kerap membagikan setiap kegiatannya baik bersama keluarganya, bersama masyarakat sekitar dan juga urusan politiknya di berbagai Negara yang ada, beliau memperlihatkannya melalui postingan Instagramnya.

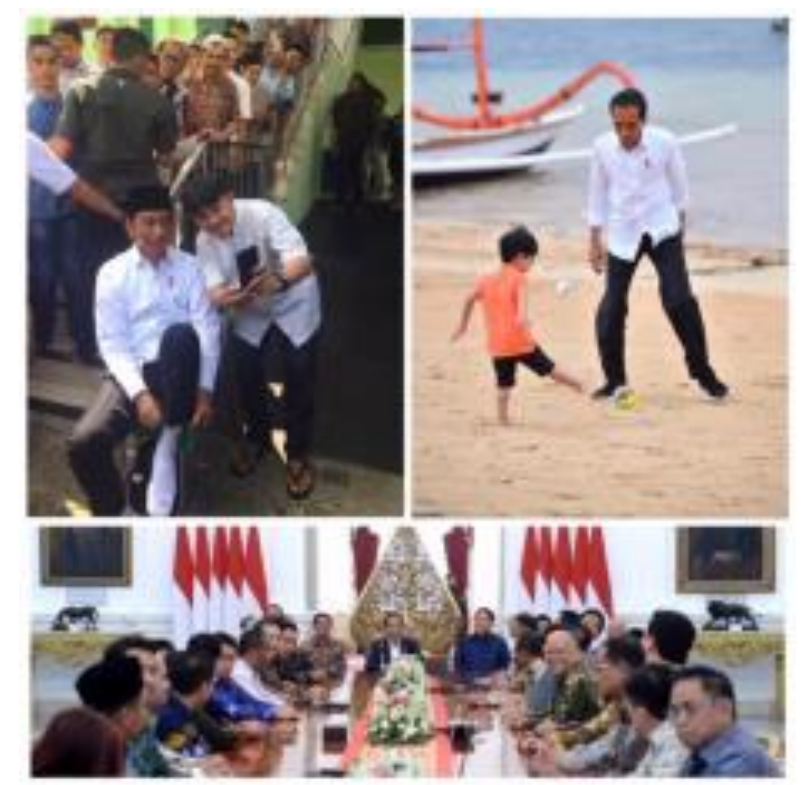

Gambar 1: Instagram Jokowi (Sumber: Data Online Instagram) 
Dari beberapa foto yang diposting di Instagram Presiden Republik Indonesia Joko Widodo (@Jokowi), beliau sangat peduli terhadap keluarga, masyarakat, dan juga politik. Beliau sangat memperhatikan setiap citranya terhadap 3 hal tersebut. Beliau membangun hubungannya baik tampak dari dalam maupun dari luar dalam setiap postingan yang diunggah melalui Instagram beliau hamper setiap harinya.

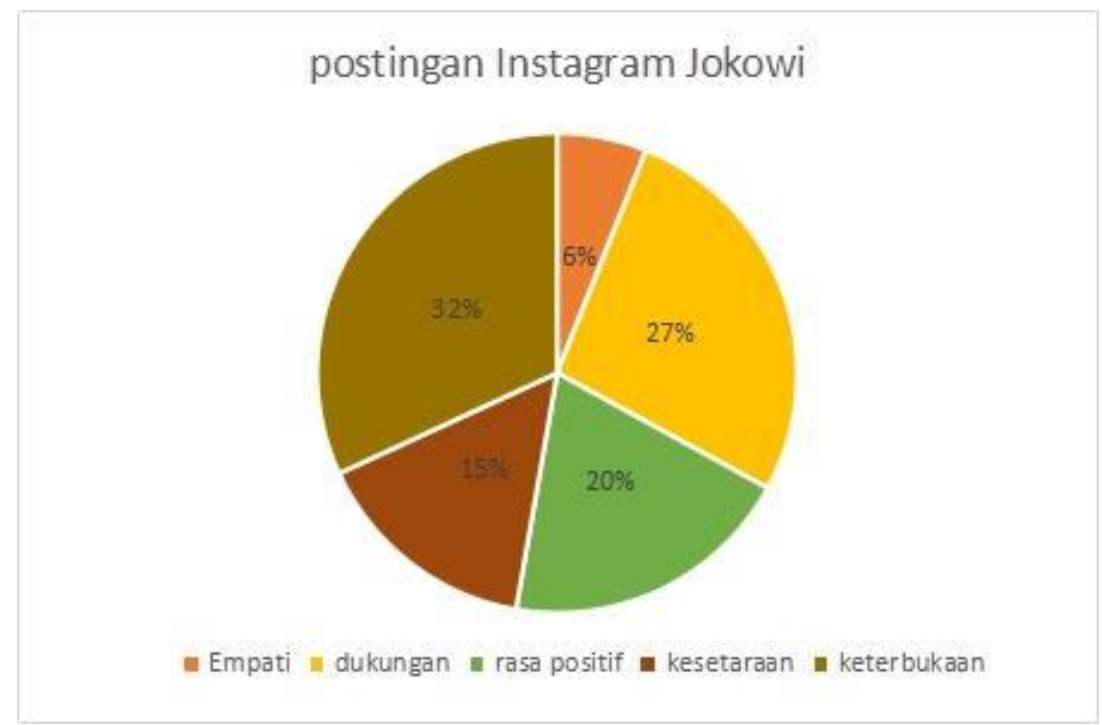

Grafik 2: Analisis Instagram Jokowi

Adapun fungsi citra diri dalam Devito (2010) dalam postingan Instagram Presiden Jokowi meliputi lima aspek seperti keterbukaan, empati, rasa positif, kesetaraan, dukungan. Dalam grafik diatas tampak bahwa Jokowi relatif lebih banyak memposting dirinya dengan menunjukkan citra dirinya terhadap rasa keterbukaan sebanyak 58 postingan dari total 182 postingan di bulan Juni-Agustus 2019.. Dapat dilihat yang di dalam grafik tersebut bahwa empatinya sebanyak 11 buah postingan, dan dukungan sebanyak 49 buah postingan, rasa positif sebanyak 36 buah postingan, kesetaraan sebanyak 28 buah postingan, dan keterbukaan sebanyak 58 buah postingan dari total keseluruhan 182 postingan yang ada. Presiden Jokowi kerap memberikan keterbukaannya di postingan Instagram beliau karena berdasarkan penelitian, Presiden Jokowi kerap memposting tentang keterbukaan sebanyak 58 buah postingan dan menunjukkan keterbukaan tersebut ke dalam citra masyarakat dibandingkan postingan tentang lainnya. Sebuah komunikasi interpersonal menurut Joseph DeVito dalam Alo Liliweri baru dapat dikatakan efektif bilamana di dalamnya terdapat keterbukaan, empati, bersifat mendukung, bersikap positif dan meletakan diri sejajar (Liliweri, 1997). 


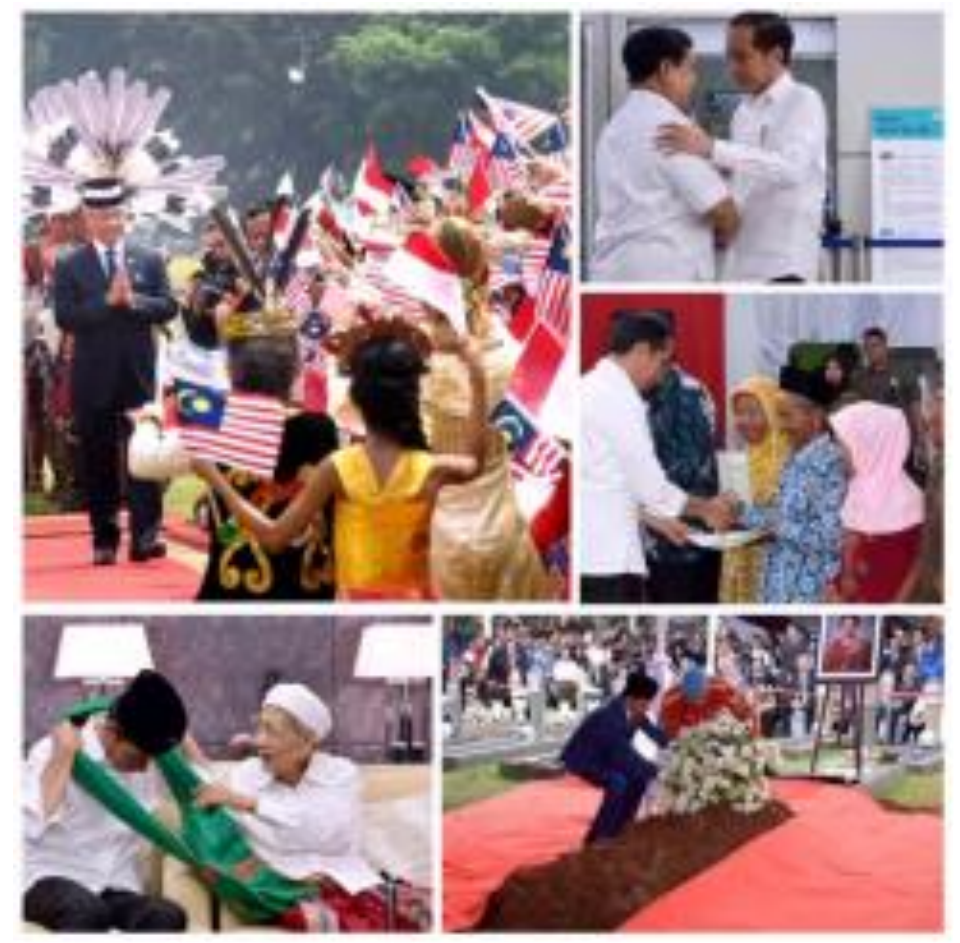

Gambar 2: Instagram Jokowi (Sumber: Data Online Instagram)

Dalam setiap postingan yang Jokowi posting dalam Instagram beliau. Beliau sangat menunjukkan citra dirinya dalam setiap postingannya baik dalam sifat keterbukaan, empati, dukungan, bahkan sikap positifnya seperti yang beliau tunjukkan pada postingan beliau bersama Prabowo dan beliau sangat menunjukan kepada setiap masyarakat, politik dan keluarga yang ada di setiap postingan Instagramnya.

\section{Simpulan}

Media Instagram Presiden Jokowi sangat aktif dan kerap dapat dilihat oleh seluruh masyarakat yang ada bahkan Presiden Jokowi merupakan sebagai Presiden pertama Indonesia yang memiliki media sosial Instagram. Dalam Instagram Presiden Jokowi beliau sangat menunjukan citra diri nya melalui setiap postingan yang ada sebagai sarana untuk menunjukkan citra dirinya terhadap masyarakat pengguna media sosial Instagram.

Adapun citra diri seorang Jokowi yang ditampilkan oleh beliau dalam 3 kategori citra yaitu terhadap politik, masyarakat, dan keluarga dan juga berdasarkan menurut DeVito (2010) dalam setiap postingan Instagram Jokowi yang sangat menunjukkan citra dirinya dalam keterbukaan dibandingkan rasa positif, kesetaraan, dukungan, dan empati. Setiap postingan Instagram Jokowi yang ditampilkan dengan adanya citra dirinya dalam keterbukaan kepada masyarakat pengguna media sosial Instagram.

\section{Ucapan Terima Kasih}

Penulis ingin mengucapkan terima kasih sebesar-besarnya kepada semua pihak yang telah mendukung, dan membantu dalam menyelesaikan penelitian ini sampai dengan selesai dan dapat berjalan lancar tanpa suatu hambatan yang ada. 


\section{Daftar Pustaka}

Andreas, Kaplan M \& Haenlein Michael (2010). Users of the world unite! The challenges and opportunities of social media. Business Horizons 53 (1). P. 61.

Azeharie. Penyikapan diri Ibas Yudhoyono Dalam Instagram dan reaksi Ani Yudhoyono terhadap postingan Instagram Ibas. Vol 7, No.1 (2015).

Bungin, Burhan. (2010). Metode Penelitian Kualitatif. Jakarta: PT. Raja Grafindo Persada.

Devito, Joseph.A. (2010). Komunikasi Antarmanusia (ed.5) Tangerang Selatan: Karisma Publishing Group.

Dayaksini, T. D. (2009). Psikologi Sosial. Malang: UMM Pers.

Liliweri, Alo. (1997). Komunikasi Antarpribadi. Bandung: Citra Aditya Bakti.

Herdiansyah, Haris. (2010). Metodologi Penelitian Kualitatif: untuk Ilmu-Ilmu sosial. Jakarta: Salemba Humanika

Moleong, Lexy J. (2012). Metode Penelitian Kualitatif. Bandung: PT. Remaja Rosdakarya

Herdiansyah, Haris. (2010). Metodologi Penelitian Kualitatif: untuk Ilmu-Ilmu sosial. Jakarta: Salemba Humanika

Moleong, Lexy J. (2009). Metode Penelitian Kualitatif. Bandung: PT. Remaja Rosdakarya 